\section{Plantain-derived Diploid Hybrids (TMP2x) with Black Sigatoka Resistance}

\author{
Dirk Vuylsteke ${ }^{1}$ and Rodomiro Ortiz ${ }^{2}$ \\ Plantain and Banana Improvement Program, International Institute of Tropical \\ Agriculture, Onne Station, PMB 5320, Ibadan, Nigeria
}

Additional index words. banana, breeding, Musa, Mycosphaerella fijiensis

Plantain (Musa spp., AAB group), a triploid $(2 n=3 x=33)$ giant perennial herb of the tropics, is a natural interspecific hybrid between the two wild banana species $M$. acuminata Colla. and M. balbisiana Colla. These diploid species contributed the A and $\mathrm{B}$ genomes, respectively (Simmonds, 1962). Triploidy makes plantain crossbreeding difficult but not impossible (Swennen and Vuylsteke, 1993). As such, plantain progenies were obtained when triploid plantains were crossed with diploid $M$. acuminata clones (Vuylsteke et al., 1993c). Genetic improvement of plantain is required because its sustainable production is threatened by increasing disease and pest pressure (Vuylsteke et al., 1993b). One of the major constraints is the black sigatoka leaf spot disease (Mycosphaerella fijiensis Morelet), which causes yield losses of at least 33\% (Mobambo et al., 1993). Production and cultivation of resistant cultivars are generally considered the most appropriate means to control the disease.

The International Institute of Tropical Agriculture (IITA) targets the development of improved plantain germplasm. So far, $14 \mathrm{im}$ proved plantain-derived tetraploid $(4 \mathrm{x})$ hybrids with black sigatoka resistance have been selected for multilocational testing and further cultivar release by national agricultural research programs (Vuylsteke et al., 1993d). In addition to the tetraploid hybrids, progenies with other ploidies were also recovered from the $3 \mathrm{x} \times 2 \mathrm{x}$ crosses, diploids $(2 \mathrm{x})$ being most numerous (Vuylsteke et al., 1993c). Plantainderived diploids play an important role in

Received for publication 28 Mar. 1994. Accepted for publication 8 Sept. 1994. We thank Rony Swennen, Catholic Univ. of Leuven and formerly at The International Institute of Tropical Agriculture (IITA), for the initial crosses and Leo Oragwa and Julian Osuji for assistance in embryo culture and chromosome counting, respectively. We acknowledge the International Network for the Improvement of Banana and Plantain for making available the diploid male parent. IITA is a nonprofit organization and is a member of the Consultative Group on International Agricultural Research. Its international mailing address is IITA, c/o L.W. Lambourn and Co., Carolyn House, 26 Dingwall Rd., Croydon CR9 3EE, England. The cost of publishing this paper was defrayed in part by the payment of page charges. Under postal regulations, this paper therefore must be hereby marked advertisement solely to indicate this fact.

${ }^{1}$ Germplasm Enhancer

${ }^{2}$ Breeder/Geneticist. plantain breeding because they provide opportunity for germplasm enhancement at the diploid level and are a source of plantain alleles (Vuylsteke et al., 1993a). Their occurrence also simplifies genetic analysis due to disomic inheritance, which facilitates and accelerates breeding. For example, the genetics of black sigatoka disease resistance, dwarfism, apical dominance, fruit parthenocarpy, bunch weight, and other yield components were established using these plantain-derived diploids (Ortiz and Vuylsteke, 1993). Most significant was the elucidation of the inheritance of black sigatoka resistance in plantain, which is controlled by a major recessive gene and two minor modifier genes with additive effects (Ortiz and Vuylsteke, 1992, 1994a). The diploid germplasm is currently being used by IITA and the South Atlantic Area Regional Plant Introduction Station of the U.S. Dept. of Agriculture-Agricultural Research Service to develop a saturated molecular map of Musa.

The diploid breeding/genetic stock was developed at IITA during the period 1988-93. These potential parental clones are ready for distribution to breeders and geneticists interested in either germplasm enhancement or genetic analysis of the plantain genome.

\section{Origin}

The plantain-derived diploid hybrids (Fig. 1), hereafter referred to as TMP2x (tropical Musa plantain-derived diploid hybrids), are $\mathrm{F}_{1}$ progenies obtained from interspecific interploidy crosses (Vuylsteke et al., 1993c). The female parents were the triploid $(2 n=3 x$
= 33) "French" plantain cultivars Bobby Tannap (Cameroon); Bungaoisan (Philippines), Ntanga-2 and Obino l'Ewai (Nigeria) (Swennen, 1990); and French Reversion, a somaclonal variant of the Nigerian False Horn plantain cultivar Agbagba (Vuylsteke et al., 1991). These cultivars were selected as parents due to their relatively high female fertility (Swennen and Vuylsteke, 1993). The diploid $(2 \mathrm{n}=2 \mathrm{x}=22)$ male parent was the wild inedible banana 'Calcutta 4' (M. acuminata ssp. burmannicoides) from Burma/Myanmar (De Langhe and Devreux, 1960). 'Calcutta 4' has true-seeded fleshless nonparthenocarpic fruit because it lacks one of the three dominant complementary genes for parthenocarpy (Simmonds, 1953). Nevertheless, 'Calcutta 4' was used as male parent because it produces large quantities of fertile pollen, is black sigatoka resistant, and has been considered taxonomically related to plantain (De Langhe, 1969).

The $3 \mathrm{x} \times 2 \mathrm{x}$ crosses, which led to the production of the TMP $2 x$ germplasm, were made from 1988 to 1990 . Several thousand seeds were harvested and embryos germinated in vitro. Tetraploid and diploid progenies were initially sorted out using stomatal size and density as discriminant function (Simmonds, 1948; Vandenhout, 1993). The ploidy level of some of these hybrids was later confirmed by chromosome counts using root tips. Diploid progenies resulted from the union of normal (n $=\mathrm{x}$ ) gametes of both parents (Vuylsteke et al., 1993c).

Several hundred diploid hybrids were fieldestablished in early evaluation trials (EETs) in 1989-90, and 81 promising hybrids advanced to preliminary yield trials (PYTs) in 1991-93 (IITA, 1993). The EETs were nonreplicated trials in which one to five plants per genotype were evaluated during one production cycle $(\approx 1$ year). The first PYTs were also nonreplicated trials in which four to five plants per genotype were observed in single-row plots during two production cycles ( $\approx 2$ years). The selection criteria were partial resistance to black sigatoka disease, significantly higher bunch weight than the mean of the diploid breeding population, and general vigor. Genotype response to black sigatoka infection was measured using the method of Vakili (1968),

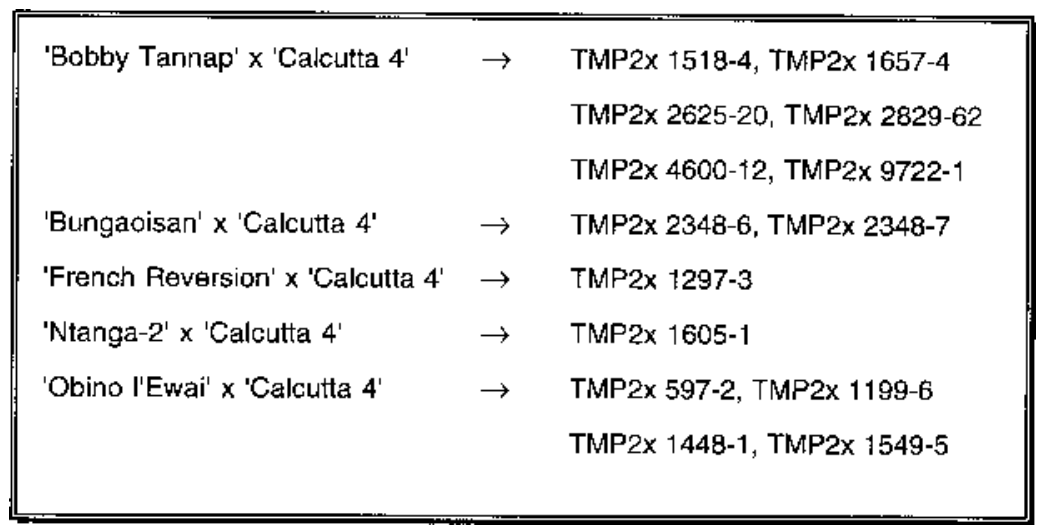

Fig. 1. Parentage of the 14 selected plantain-derived diploid hybrids (TMP2x) obtained from crossing the 3x plantains (Musa spp., AAB group) with the wild 2x 'Calcutta 4' banana. 
which consists of recording the number of the youngest leaf spotted (YLS), counting down from the first (top) unfurled leaf, on plants at flowering, which is the time when leaf production stops. YLS correlates significantly with disease development time. Therefore, increasing YLS values indicate the presence of more healthy leaves on the plant and, hence, greater resistance to the fungus. Triploid black sigatoka-susceptible plantains or bananas have on average a YLS of four to six, whereas hybrids exhibiting partial resistance have a YLS $\geq 8$ in the rainy season (Mobambo et al., 1993; Vuylsteke et al., 1993c). Growth and yield variables were evaluated at flowering and at harvest in EETs and PYTs, as described by Swennen and De Langhe (1985).

After intensive testing from 1989 to 1993 at Onne, IITA's High Rainfall Station in the humid forest zone near Port Harcourt, Nigeria, a total of 14 TMP $2 x$ clones was selected for further use as parental stock for primary tetraploids (in $3 \times \times 2 \times$ crosses) or for secondary triploids (in $4 \times \times 2 \times$ crosses).

\section{Description and performance}

The TMP2x clones are identified by their original cross/progeny number (Fig. 1). All the TMP $2 x$ have higher levels of black sigatoka resistance than their susceptible plantain parents, as determined by an evaluation of YLS. Host response to black sigatoka in the partially resistant TMP $2 \mathrm{x}$ germplasm is based on slower or delayed disease development. Less leaf spot damage ensues. Such host response seems to provide more durable resistance (Ortiz and Vuylsteke, 1994a).

Two exceptional 'Bungaoisan'-derived hybrids, TMP2x 2348-6 and TMP2x 2348-7, were initially selected due to their greater bunch weight and large parthenocarpic fruit (Table 1). In addition, these two fertile, black sigatoka-resistant TMP2x have short to medium plants and weak apical dominance, i.e., improved suckering behavior. TMP2x 2348-7 has a subhorizontal bunch, while TMP $2 x$ 2348-6 has a pendulous bunch. The latter is an economically important character because pendulous bunches are more symmetrical and, therefore, better adapted for transportation. TMP2x 2348-6 has deciduous hermaphrodite flowers, while TMP2x 2348-7 has persistent hermaphrodite flowers and exhibits male bud imbrication.

Other promising diploid hybrids derived from cultivars Bobby Tannap and Obinol'Ewai were evaluated in PYTs in plant and ratoon crops. Growth and yield characteristics of the average diploid population, the selected TMP2x, and of the male parent 'Calcutta 4' are listed in Table 2. Most of these selected TMP $2 x$ have subhorizontal bunch orientation, except TMP2x 597-2, 2829-62, and 9722-1, which have a pendulous bunch. Hermaphrodite flowers are deciduous like the male banana parent, except in TMP2x 1199-6, 16574 , and 9722-1, which have persistent hermaphrodite flowers. This is a characteristic typical of the female "French" plantains. TMP2x 1448-1, 1549-5, 1657-4, 2829-62, and 9722-1 exhibit male bud imbrication. All selected TMP2x do not show the strong apical dominance of the plantains. Moreover, TMP2x 597-2, 1199-6, 2625-20, 2829-62, and 9722-1 develop only one or two suckers freely while further suckering is inhibited. Such regulated suckering is a highly desirable, dominant trait for perennial plantain production (Ortiz and Vuylsteke, 1994b). In contrast to their plantain parents, which are male-sterile, all the diploid hybrids, except TMP2x 9722-1, are male-fertile. Also, TMP2x 597-2 and TMP $2 x$ 1657-4 did not set seed when crossed as female partners in interdiploid crosses, suggesting female sterility. TMP2x 1518-4 has good bunch configuration (Fig. 2) and a greater number of

Table 1. Black sigatoka resistance and agronomic evaluation of four selected TMP2x clones compared with the average of the plantain-derived diploid population in early evaluation trials at Onne, Nigeria, 1989-90.

\begin{tabular}{|c|c|c|c|c|c|c|c|c|c|c|}
\hline \multirow[b]{2}{*}{ Clone $^{v}$} & \multirow{2}{*}{$\begin{array}{c}\text { YLS }^{y} \text { at } \\
\text { flowering }\end{array}$} & \multirow{2}{*}{$\begin{array}{c}\text { Plant } \\
\text { ht (m) }\end{array}$} & \multirow{2}{*}{$\begin{array}{c}\text { HTS }^{\mathrm{x}} \text { at } \\
\text { harvest }(\mathrm{m})\end{array}$} & \multirow{2}{*}{$\begin{array}{l}\text { Bunch } \\
\text { wt (kg) }\end{array}$} & \multirow{2}{*}{$\begin{array}{c}\text { Hands } \\
\text { (no.) }\end{array}$} & \multirow{2}{*}{$\begin{array}{l}\text { Fruit } \\
\text { (no.) }\end{array}$} & \multicolumn{3}{|c|}{ Fruit } & \multirow{2}{*}{$\begin{array}{c}\begin{array}{c}\text { Filling } \\
\text { time }^{w} \\
\text { (days) }\end{array} \\
\end{array}$} \\
\hline & & & & & & & $\mathrm{Wt}(\mathrm{g})$ & Length $(\mathrm{cm})$ & Girth $(\mathrm{cm})$ & \\
\hline TMP2x 2348-6 & 10 & 2.7 & 2.9 & 13.9 & 8 & 126 & 98 & 15 & 10 & 139 \\
\hline TMP2x 2348-7 & 9 & 2.2 & 2.9 & 15.2 & 7 & 117 & 130 & 15 & 10 & 165 \\
\hline TMP2x 597-2 & 9 & 3.6 & 1.9 & 7.8 & 7 & 108 & 72 & 18 & 10 & 118 \\
\hline TMP2x 1448-1 & 9 & 3.5 & 3.2 & 6.0 & 8 & 161 & 33 & 11 & 9 & 181 \\
\hline $2 \mathrm{x}$ population ${ }^{\mathrm{u}}$ & $8 \pm 0.2$ & $2.5 \pm 0.1$ & $2.5 \pm 0.1$ & $4.3 \pm 0.7$ & $6 \pm 0.2$ & $92 \pm 6$ & $46 \pm 6$ & $11 \pm 1$ & $10 \pm 1$ & $115 \pm 6$ \\
\hline
\end{tabular}

${ }^{2}$ Growth and yield variables measured according to Swennen and De Langhe (1985).

${ }^{y}$ Genotype response to black sigatoka disease measured using youngest leaf spotted (YLS) according to Vakili (1968).

${ }^{x}$ HTS $=$ height of tallest sucker (follower) at harvest of main pseudostem.

"Time from inflorescence emergence to harvest.

${ }^{\vee}$ See Fig. 1 for parentage.

"Mean \pm SE, $n=32$ clones.

Table 2. Black sigatoka resistance and agronomic evaluation of 10 selected TMP2x clones compared with the performance of their diploid male parent 'Calcutta 4' and the average of the plantain-derived diploid population in preliminary yield trials at Onne, Nigeria, 1991-93 (plant and first-ratoon crops). ${ }^{2}$

\begin{tabular}{|c|c|c|c|c|c|c|c|c|c|c|}
\hline \multirow[b]{2}{*}{ Clone $^{\mathrm{w}}$} & \multirow{2}{*}{$\begin{array}{c}\text { YLS }^{y} \text { at } \\
\text { flowering }\end{array}$} & \multirow{2}{*}{$\begin{array}{l}\text { Plant } \\
\text { ht (m) }\end{array}$} & \multirow{2}{*}{$\begin{array}{c}\operatorname{HTS}^{\mathrm{x}} \text { at } \\
\text { harvest }(\mathrm{m})\end{array}$} & \multirow{2}{*}{$\begin{array}{l}\text { Bunch } \\
\text { wt (kg) }\end{array}$} & \multirow{2}{*}{$\begin{array}{c}\text { Hands } \\
\text { (no.) }\end{array}$} & \multirow{2}{*}{$\begin{array}{l}\text { Fruit } \\
\text { (no.) }\end{array}$} & \multicolumn{3}{|c|}{ Fruit } & \multirow{2}{*}{$\begin{array}{l}\text { Filling } \\
\text { time } \\
\text { (days) }\end{array}$} \\
\hline & & & & & & & $\overline{\mathrm{Wt}(\mathrm{g})}$ & Length $(\mathrm{cm})$ & Girth $(\mathrm{cm})$ & \\
\hline TMP2x 597-2 & 10 & $3.6^{*}$ & $3.5^{*}$ & $7.4^{*}$ & 6 & 94 & $79^{*}$ & $15^{*}$ & $10^{*}$ & $125^{*}$ \\
\hline TMP2x 1199-6 & 10 & $3.1^{*}$ & 2.5 & $8.3^{*}$ & 7 & 125 & $65^{*}$ & $16^{*}$ & $9^{*}$ & 115 \\
\hline TMP 2 x 1448-1 & 9 & $3.1^{*}$ & 3.3 & $5.8^{*}$ & 7 & 122 & $50^{*}$ & $13^{*}$ & $8^{*}$ & $125^{*}$ \\
\hline TMP2X 1518-4 & 10 & $3.4^{*}$ & 2.6 & $5.6^{*}$ & $9^{*}$ & 146 & $54^{*}$ & $13^{*}$ & $6^{*}$ & 103 \\
\hline TMP2X 1549-5 & 10 & $3.6^{*}$ & 2.8 & $5.8^{*}$ & $10^{*}$ & $187^{*}$ & $35^{*}$ & $13^{*}$ & $7^{*}$ & $117^{*}$ \\
\hline TMP $2 \times 1657-4$ & 9 & $3.1^{*}$ & 2.7 & $7.9^{*}$ & 8 & 155 & $48^{*}$ & $13^{*}$ & $8^{*}$ & $125^{*}$ \\
\hline TMP $2 \times 2625-20$ & 12 & 2.6 & 2.6 & $7.9^{*}$ & 8 & 112 & $69^{*}$ & $14^{*}$ & $10^{*}$ & $149^{*}$ \\
\hline TMP $2 \times 2829-62$ & 11 & $3.4^{*}$ & 2.8 & $5.5^{*}$ & 8 & 137 & $35^{*}$ & $14^{*}$ & $7^{*}$ & $123^{*}$ \\
\hline TMP $2 \times$ 4600-12 & 12 & $2.9^{*}$ & 2.5 & $6.1^{*}$ & 7 & 107 & $55^{*}$ & $11^{*}$ & $8^{*}$ & $143^{*}$ \\
\hline TMP2x 9722-1 & $12^{v}$ & $3.0^{*}$ & 2.8 & $5.7^{*}$ & $9^{*}$ & 142 & $39^{*}$ & $14^{*}$ & $7^{*}$ & $87^{*}$ \\
\hline $2 \mathrm{x}$ population ${ }^{\mathrm{u}}$ & $8 \pm 0.2$ & $2.6 \pm 0.2$ & $2.2 \pm 0.1$ & $3.0 \pm 0.2$ & $6 \pm 0.1$ & $95 \pm 4$ & $32 \pm 2$ & $11 \pm 0.3$ & $7 \pm 0.2$ & $117 \pm 3$ \\
\hline Calcutta 4 & $--^{v}$ & $2.2 \pm 0.2$ & $2.8 \pm 0.2$ & $0.8 \pm 0.3$ & $7 \pm 0.2$ & $113 \pm 15$ & $6 \pm 2$ & $5 \pm 1$ & $3 \pm 1$ & $104 \pm 4$ \\
\hline
\end{tabular}

${ }^{2}$ Growth and yield variables measured according to Swennen and De Langhe (1985).

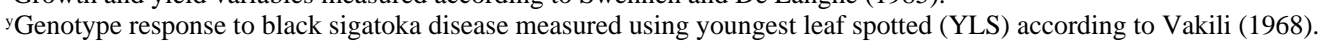

${ }^{x} \mathrm{HTS}=$ height of tallest sucker (follower) at harvest of main pseudostem.

${ }^{w}$ See Fig. 1 for parentage.

${ }^{v}$ Highly resistant to black sigatoka; leaf spots not readily observed.

"Mean $\pm \mathrm{SE}, \mathrm{n}=81$ clones.

*Significant at $P \leq 0.05$ for multiple comparison within columns of TMP2x genotypes with their male diploid parent 'Calcutta 4 '. Critical values of Student's $t$ distribution were adjusted by Sidak's multiplicative inequality based on $\alpha^{1}=1-(1-\alpha) 1 / \mathrm{c}$, in which $\alpha^{1}$ is the level of significance required for statistical testing and $\mathrm{c}$ is the number of comparisons between the hybrids and 'Calcutta 4', i.e., 10 (Sokal and Rohlf, 1981). 


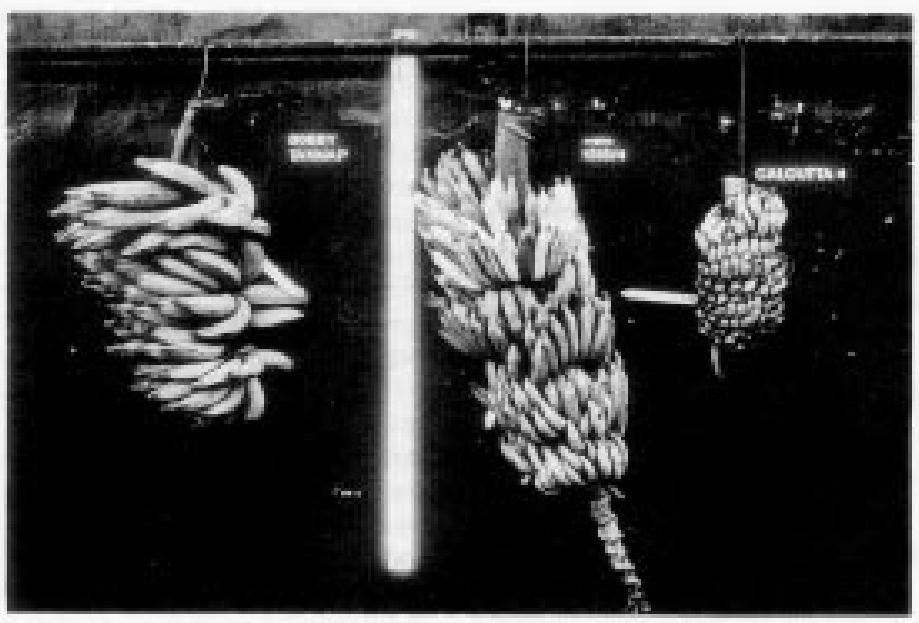

Fig. 2. Black-sigatoka-resistant, plantain-derived diploid hybrid TMP2x 1518-4 (center), obtained from crossing the $3 \mathrm{x}$ susceptible 'Bobby Tannap' plantain (left) with the highly resistant wild $2 \mathrm{x}$ 'Calcutta 4' banana (right).

hands and fruit than most of the other diploid selections (Table 2).

Another two clones, TMP2x 1297-3 and TMP2x 1605-1, were also selected in 198991. The black-sigatoka-resistant TMP2x 12973 and 1605-1 have weak apical dominance and high-yielding, subhorizontal (to almost pendulous) bunches with parthenocarpic fruit. These two diploid hybrids show striking morphological resemblance to the "French" plantains and may be genetically close to the lost diploid progenitor(s) that played a key role in the phylogeny of the triploid plantain germplasm (De Langhe, 1993). TMP2x 16051 , a trisomic $(2 n=2 x+1=23)$ derived from the giant plantain cultivar Ntanga-2, is malesterile but female-fertile. TMP2x 1297-3 is a diploid derived from the 'French Reversion' somaclonal variant of 'Agbagba'. TMP2x 1297-3 offers the opportunity to breed in the previously inaccessible False Horn plantain gene pool (IITA, 1993). For example, TMP2x 1297-3 was crossed with its full-sib tetraploid TMPx 1112-1 to produce secondary triploid segregating offspring in which directional selection for large fruit size was applied. This breeding scheme aims to develop improved Musa germplasm with fruit size and quality similar to the preferred False Horn plantains.

Most of the improved plantain-derived diploids were crossed with primary TMPX tetraploids (Vuylsteke et al., 1993d) to assess their breeding value (IITA, 1993). Several secondary triploids, combining short to medium plant stature, high levels of black sigatoka resistance, weak apical dominance or regulated suckering, pendulous bunches with parthenocarpic fruit, and acceptable yields, were identified in the segregating populations. This was expected because promising tetraploid hybrids (TMPx) were selected earlier even when using a wild, nonselected male parent such as 'Calcutta 4' (Vuylsteke et al., 1993c). Segregation for plant size was expected because all hybrids are carriers of the recessive dwarfism $(d w)$ gene (Ortiz and Vuylsteke,
1993). Moreover, TMP2x likely will produce offspring with more plantain-like characteristics than progenies derived from 'Calcutta 4', because TMP2x have $50 \%$ plantain genes in their genome. This genetic background may be important for improving fruit quality in the plantain breeding population. Also, plantain progenies derived from selected TMP $2 x$ likely have the same degree of black sigatoka resishave the same genotype for partial resistance to black sigatoka (Ortiz and Vuylsteke, 1994a).

\section{Availability}

Limited numbers of in vitro plantlets are available upon request. Researchers interested in using TMP2x germplasm as a source of plantain alleles for development of improved Musa populations in their breeding programs should write to the Leader, Plantain and $\mathrm{Ba}$ nana Improvement Program, IITA, c/o Lambourn \& Co., Carolyn House, 26Dingwall Rd., Croydon CR9 3EE, England. Recipients are asked to give appropriate recognition of the germplasm source if it is used in developing a new germplasm, parental line, or cultivar.

\section{Literature Cited}

De Langhe, E. 1969. Bananas (Musa spp.), p. $53-$ 78. In: F.P. Ferwarda and F. Wit (eds.). Outlines of perennial crop breeding in the tropics. Misc. Papers no. 4, Agr. Univ., Wageningen, The Netherlands.

De Langhe, E. 1993. Genetic improvement of banana and plantain: The new era, p. 1-9. In: J. Ganry (ed.). Breeding banana and plantain for resistance to diseases and pests. Proc. Intl. Symp., Montpellier, France, 7-9 Sept. 1992. Centre de Coopération Internationale en Recherche Agronomique pour le Développement, Montpellier, France.

De Langhe, E. and M. Devreux. 1960. Une sousespèce nouvelle de Musa acuminata Colla. Bul. Jard. Bot. Brux. 30:375-388.

International Institute of Tropical Agriculture. 1993 Plantain/banana improvement program, annual tance as progenies of 'Calcutta 4' because they report 1992. Crop Improvement Div., Intl. Inst. Trop. Agr., Ibadan, Nigeria.

Mobambo, K.N. et al. 1993. Yield loss in plantain from black sigatoka leaf spot and field performance of resistant hybrids. Field Crops Res. 35:35-42.

Ortiz, R. and D. Vuylsteke. 1992. Inheritance of black sigatoka resistance and fruit parthenocarpy in triploid AAB plantain. Agron. Abstr. p. 109.

Ortiz, R. and D. Vuylsteke. 1993. The genetics of black sigatoka resistance, growth, and yield parameters in $4 x$ and $2 x$ plantain-banana hybrids, p. 379. In: J. Ganry (ed.). Breeding banana and plantain for resistance to diseases and pests. Proc. Intl. Symp., Montpellier, France, 7-9Sept. 1992. Centre de Coopération Internationale en Recherche Agronomique pour le Développement, Montpellier, France. (Abstr.)

Ortiz, R. and D. Vuylsteke. 1994a. Inheritance of black sigatoka disease resistance in plantainbanana (Musa spp.) hybrids. Theor. Appl. Genet. (In press.)

Ortiz, R. and D. Vuylsteke. 1994b. Genetics of apical dominance in plantain (Musa spp., AAB group) and improvement of suckering behavior. J. Amer. Soc. Hort. Sci. 119:1050-1053.

Simmonds, N.W. 1948. Genetical and cytological studies of Musa.X. Stomatal size and plant vigor in relation to polyploidy. J. Genet. 49:57-68.

Simmonds, N.W. 1953. Segregations in some diploid bananas. J. Genet. 51:458-469.

Simmonds, N.W. 1962. The evolution of the bananas. Longmans, London.

Sokal, R.R. and F.J. Rohlf. 1981. Biometry. 2nd ed. W.H. Freeman, New York.

Swennen, R. 1990. Limits of morphotaxonomy: Names and synonyms of plantain in Africa and elsewhere, p. 172-210. In: R.L. Jarret (ed.). Identification of genetic diversity in the genus Musa. Proc. Intl. Wkshp., Los Baños, Philippines, 5-10 Sept. 1988. Intl. Network for the Improvement of Banana and Plantain, Montpellier, France.

Swennen, R. and E. De Langhe. 1985. Growth parameters of yield of plantain (Musa spp. cv. AAB). Ann. Bot. 56:197-204.

Swennen, R. and D. Vuylsteke. 1993. Breeding black sigatoka resistant plantains with a wild banana. Trop. Agr. (Trinidad) 70:74-77.

Vakili, N.G. 1968. Responses of Musa acuminata species and edible cultivars to infection by Mycosphaerella musicola. Trop. Agr.(Trinidad) 45:13-22.

Vandenhout, H. 1993. Effect van het ploidieniveau op de morfologie bij banaan (Musa spp.). MS Thesis (in Dutch). Catholic Univ. of Leuven, Belgium.

Vuylsteke, D., R. Ortiz, and R.S.B. Ferris. 1993a. Genetic and agronomic improvement for sustainable production of plantain and banana in Sub-Saharan Africa. African Crop Sci. J. 1:1-8.

Vuylsteke, D. et al. 1993b. Plantain and banana research at the International Institute of Tropical Agriculture. HortScience 28:873-874,970-971.

Vuylsteke, D., R. Swennen, and E. De Langhe. 1991. Somaclonal variation in plantains (Musa spp, AAB group) derived from shoot-tip culture. Fruits 46:429-439.

Vuylsteke, D., R. Swennen, and R. Ortiz. 1993c. Development and performance of black sigatokaresistant tetraploid hybrids of plantain (Musa spp, AAB group). Euphytica 65:33-42.

Vuylsteke, D., R. Swennen, and R. Ortiz. 1993d. Registration of 14 improved tropical Musa plantain hybrids with black sigatoka resistance. HortScience 28:957-959. 